\title{
Comparison of the Sulfonamide Inhibition Profiles of the $\beta$ - and $\gamma$-Carbonic Anhydrases from the Pathogenic Bacterium Burkholderia pseudomallei
}

\author{
Daniela Vullo ${ }^{1, *}$, Sonia Del Prete ${ }^{2,3}$, Pietro Di Fonzo ${ }^{2}$, Vincenzo Carginale ${ }^{2}$, \\ W. Alexander Donald ${ }^{4}$, Claudiu T. Supuran ${ }^{3,4}$ and Clemente Capasso ${ }^{2, *}$ \\ 1 Laboratorio di Chimica Bioinorganica, Dipartimento Di Chimica, Università degli Studi di Firenze, \\ Polo Scientifico, Via della Lastruccia 3, 50019 Sesto Fiorentino, Florence, Italy \\ 2 Istituto di Bioscienze e Biorisorse, CNR, Via Pietro Castellino 111, 80131 Napoli, Italy; \\ sonia.delprete@unifi.it (S.D.P.); pidifo@gmail.com (P.D.F.); vincenzo.carginale@cnr.it (V.C.) \\ 3 Sezione di Scienze Farmaceutiche e Nutraceutiche, Dipartimento Neurofarba, \\ Università degli Studi di Firenze, Via U. Schiff 6, 50019 Sesto Fiorentino, Florence, Italy; \\ claudiu.supuran@unifi.it \\ 4 School of Chemistry, University of New South Wales, Sydney, New South Wales 2052, Australia; \\ w.donald@unsw.edu.au \\ * Correspondence: Daniela daniela.vullo@unifi.it (D.V.); clemente.capasso@ibbr.cnr.it (C.C.); \\ Tel./Fax: +39-055-457-3005 (D.V.); +39-081-613-2559 (C.C.)
}

Academic Editors: Derek J. McPhee and Diego Muñoz-Torrero

Received: 6 February 2017; Accepted: 3 March 2017; Published: 7 March 2017

\begin{abstract}
We have cloned, purified, and characterized a $\beta$-carbonic anhydrase (CA, EC 4.2.1.1), BpsCA $\beta$, from the pathogenic bacterium Burkholderia pseudomallei, responsible for the tropical disease melioidosis. The enzyme showed high catalytic activity for the physiologic $\mathrm{CO}_{2}$ hydration reaction to bicarbonate and protons, with the following kinetic parameters: $\mathrm{k}_{\text {cat }}$ of $1.6 \times 10^{5} \mathrm{~s}^{-1}$ and $\mathrm{k}_{\text {cat }} / \mathrm{K}_{\mathrm{M}}$ of $3.4 \times 10^{7} \mathrm{M}^{-1} \cdot \mathrm{s}^{-1}$. An inhibition study with a panel of 38 sulfonamides and one sulfamate-including 15 compounds that are used clinically-revealed an interesting structure-activity relationship for the interaction of this enzyme with these inhibitors. Many simple sulfonamides and clinically used agents such as topiramate, sulpiride, celecoxib, valdecoxib, and sulthiame were ineffective BpsCA $\beta$ inhibitors $\left(K_{I}>50 \mu \mathrm{M}\right)$. Other drugs, such as ethoxzolamide, dorzolamide, brinzolamide, zonisamide, indisulam, and hydrochlorothiazide were moderately potent micromolar inhibitors. The best inhibition was observed with benzene-1,3-disulfonamides-benzolamide and its analogs acetazolamide and methazolamide-which showed $\mathrm{K}_{\mathrm{I}}$ in the range of $185-745 \mathrm{nM}$. The inhibition profile of BpsCA $\beta$ is very different from that of the $\gamma$-class enzyme from the same pathogen, BpsCA $\gamma$. Thus, identifying compounds that would effectively interact with both enzymes is relatively challenging. However, benzolamide was one of the best inhibitors of both of these CAs with $K_{I}$ of 653 and $185 \mathrm{nM}$, respectively, making it an interesting lead compound for the design of more effective agents, which may be useful tools for understanding the pathogenicity of this bacterium.
\end{abstract}

Keywords: carbonic anhydrase; metalloenzymes; pathogens; $\beta$-class; sulfonamide; Burkholderia pseudomallei

\section{Introduction}

Our groups started to investigate the biochemical properties, kinetic constants and inhibition profiles of numerous classes of carbonic anhydrases (CAs; EC 4.2.1.1) in different species of pathogenic and non-pathogenic bacteria (see Table 1). CAs are ubiquitous metalloenzymes that catalyze the reversible hydration of carbon dioxide with the production of bicarbonate and protons. The CA 
superfamily includes seven distinct classes known as the $\alpha, \beta, \gamma, \delta, \zeta, \eta$, and $\theta[1-13]$. The $\alpha-, \beta-, \delta_{-}, \eta_{-}^{-}$, and perhaps $\theta$-CAs use $\mathrm{Zn}$ (II) ions at the active site, the $\gamma$-CAs are probably Fe(II) enzymes (but they are also active with bound $\mathrm{Zn}(\mathrm{II})$ or $\mathrm{Co}(\mathrm{II})$ ions) [14-21], and the $\zeta$-class CAs are cambialistic enzymes, active both with $\mathrm{Cd}(\mathrm{II})$ or $\mathrm{Zn}$ (II) bound within the active site in order to perform the physiologic reaction catalysis [22-24]. The metal ion from the CA active site is coordinated by three His residues in the $\alpha_{-}, \gamma_{-}, \delta_{-}$, and probably $\theta$-classes, by one His and two Cys residues in $\beta$ - and $\zeta$-CAs, or by two His and one Gln residues in the $\eta$-class, with the fourth ligand being a water molecule/hydroxide ion acting as nucleophile in the catalytic cycle of the enzyme [11,25-30]. All CAs identified in animal systems belong to $\alpha$-class. CAs identified in plants and algae belong to the $\alpha_{-}, \beta-, \gamma_{-}, \delta-$, and $\theta$-classes; fungi encode for $\alpha$ - and $\beta$-CAs; protozoa encode for $\alpha-, \beta-$, or $\eta$-CAs. As shown in Table 1 , bacteria encode for enzymes belonging to the $\alpha-, \beta-$, and $\gamma$-CA classes [11,12,27,29,31-33]. Moreover, as described in literature, the genome of Gram-negative bacteria belonging to the genera Buchnera and Rickettsia does not encode for any CAs [29]. Thus, the distribution pattern of CAs in bacteria is very fascinating [29]. In the last year, it has been demonstrated in vivo that the inhibition of bacterial CAs influences the pathogenicity and/or the growth of the microorganism [27,34-39]. These promising data on live bacteria allow us to propose bacterial CAs inhibition as an approach for obtaining anti-infective agents with a new mechanism of action compared to classical antibiotics. At present, infectious diseases are the second-leading cause of death in the world, and the development of bacterial antibiotic-resistance is an inevitable and widespread phenomenon inherent to most drugs. Several classes of CA inhibitors (CAIs) are known to date, among which the metal complexing anions and sulfonamides and their bioisosteres are the most investigated for the inhibition of the bacterial CAs [12,40-44]. Anions such as the inorganic metal-complexing or more complicated species such as the carboxylates bind to CAs, but generally with less efficiency compared to the sulfonamides [45]. Anions may bind either the tetrahedral geometry of the metal ion or as trigonal-bipyramidal adducts [45]. The antibiotic revolution in medicine was represented by sulfonamides, which were the first antimicrobial drugs (Figure 1) [31,41]. Sulfonamide derivatives that were used clinically, including acetazolamide, methazolamide, ethoxzolamide, dichlorophenamide, dorzolamide, and brinzolamide, bind in a tetrahedral geometry to the $\mathrm{Zn}$ (II) ion in deprotonated state, with the nitrogen atom of the sulfonamide moiety coordinated to $\mathrm{Zn}$ (II) and an extended network of hydrogen bonds involving amino acid residues Thr199 and Glu106 (numbering system used for the human CA, isoform I) also participating in the anchoring of the inhibitor molecule to the metal ion $[31,41,46]$. The aromatic/heterocyclic part of the inhibitor interacts with hydrophilic and hydrophobic residues of the cavity. The protein fold in the diverse CA classes (seven CA-classes) is highly different [14-21], mainly due to their different oligomeric state. Successful inhibition studies with sulfonamides should allow the discovery of highly isoform-selective CAIs, which may lead to a new generation of drugs targeting these widespread enzymes.

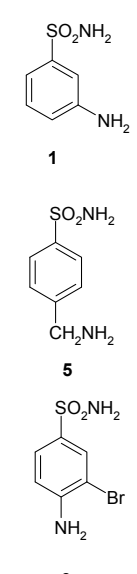

9
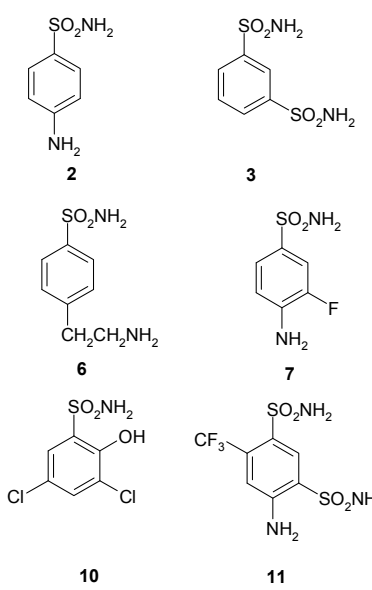

3<smiles>Cc1ccc(S(N)(=O)=O)cc1</smiles>

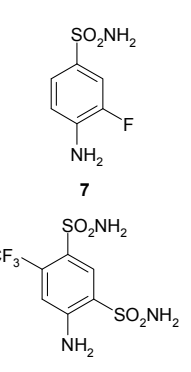

4
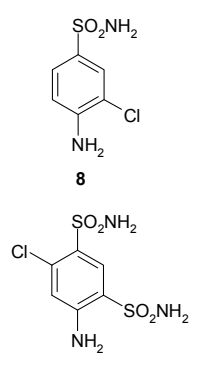

11

12

Figure 1. Cont. 

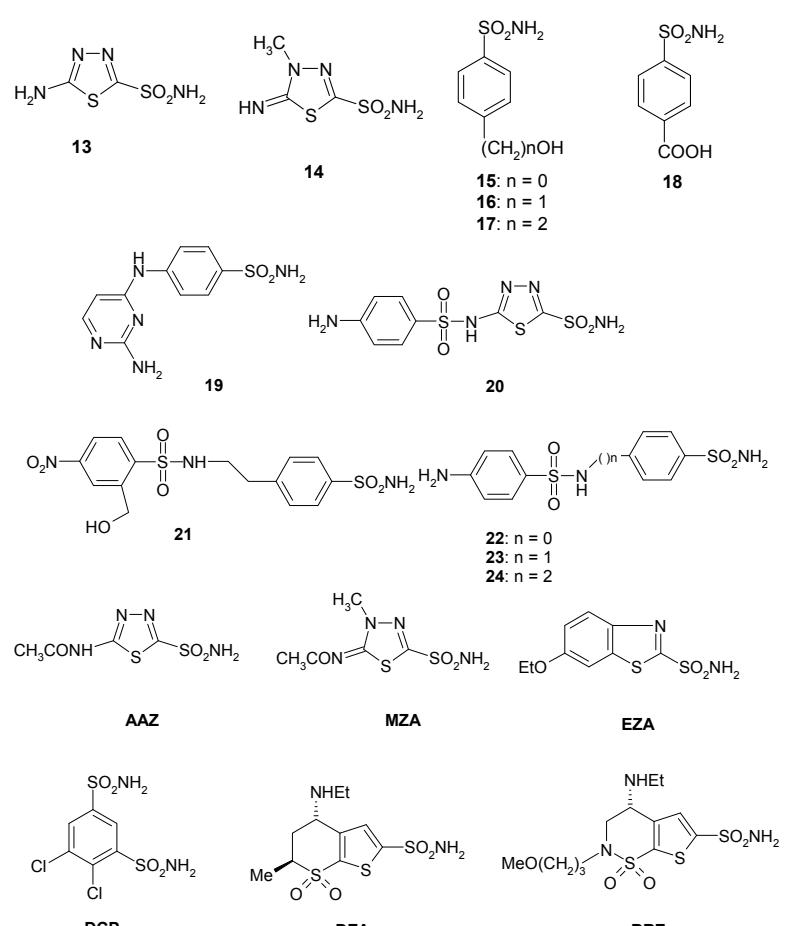

DCP

DZA

BRZ
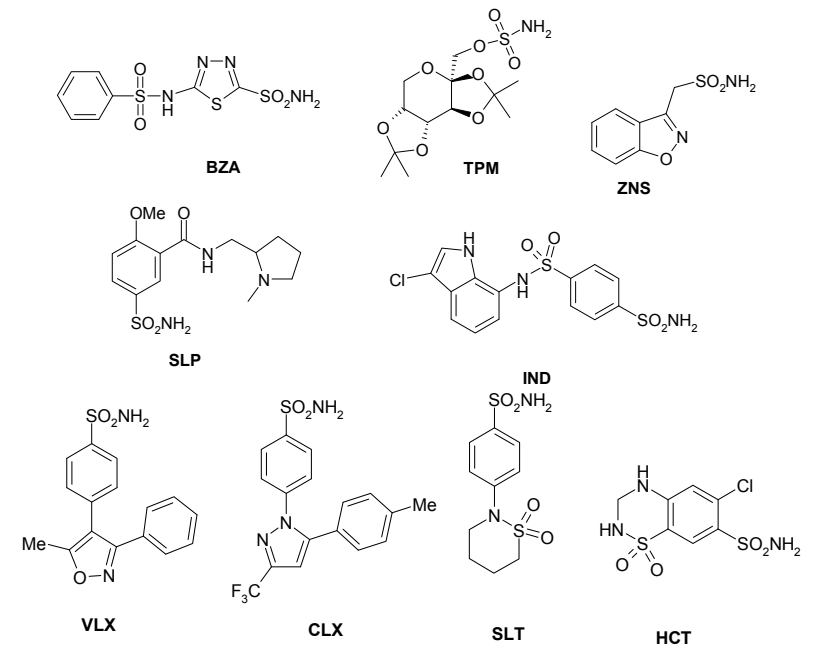

ZNS

Figure 1. Structure of sulfonamides/sulfamates investigated in the present study. AAZ: acetazolamide; BRZ: brinzolamide; BZA: benzolamide; CLX: celecoxib; DCP: dichlorophenamide; DZA: dorzolamide; EZA: ethoxzolamide; HCT: hydrochlorothiazide; IND: indisulam; MZA: methazolamide; SLP: sulpiride; SLT: sulthiame; TPM: topiramate; VLX: valdecoxib; ZNS: zonisamide.

In this context, we cloned, expressed, and purified the recombinant $\beta$-CA (BpsCA $\beta$, Accession number: WP_004550949.1) identified in the genome of Burkholderia pseudomallei, a Gram-negative saprophytic bacteria responsible of melioidosis, which is an endemic disease of tropical and sub-tropical regions [47]. The B. pseudomallei genome encodes for only $\beta$ - and $\gamma$-CAs. In the present manuscript, the inhibition profile of $\mathrm{BpsCA} \beta$ was investigated using a wide series of sulfonamides/sulfamates. The inhibition profile of BpsCA $\beta$ was compared with those obtained for the human $\alpha$-CAs (hCA I and hCAII) and the other bacterial BpsCA $\gamma$ previously identified in the genome of Burkholderia pseudomallei [7] and investigated by our groups for its inhibition profiles with anions and sulfonamides. This study may be of interest for designing new types of inhibitors that may have clinical applications, because Burkholderia pseudomallei is fundamentally resistant to penicillin, ampicillin, first-generation and second-generation cephalosporins, macrolides, quinolones, and most aminoglycosides [48]. 
Table 1. Bacterial carbonic anhydrases (CAs) investigated by our groups for their biochemical properties, kinetic constants, and inhibition profiles.

\begin{tabular}{|c|c|c|c|c|c|c|}
\hline \multirow{2}{*}{ Bacterium } & \multicolumn{2}{|c|}{ CA } & \multicolumn{2}{|c|}{ Characteristics } & \multicolumn{2}{|c|}{ Inhibition } \\
\hline & Class & Acronym & Pathogenicity & Disease & Sulfonamides & Anions \\
\hline \multirow{3}{*}{ Vibrio cholerae $[8,49,50]$} & $\alpha$ & $\mathrm{V} \operatorname{chCA} \alpha$ & + & Cholera & + & + \\
\hline & $\beta$ & $\operatorname{VchCA} \beta$ & & & + & + \\
\hline & $\gamma$ & VchCA $\gamma$ & & & + & + \\
\hline \multirow{2}{*}{ Helicobacter pylori $[36,51,52]$} & $\alpha$ & hp $\alpha \mathrm{CA}$ & \multirow[t]{2}{*}{+} & \multirow{2}{*}{$\begin{array}{c}\text { Gastritis, gastric } \\
\text { ulcers }\end{array}$} & + & + \\
\hline & $\beta$ & hp $\beta C A$ & & & + & + \\
\hline Streptococcus mutans $[11,53,54]$ & $\beta$ & SmuCA & + & Caries & + & + \\
\hline Haemophilus influenzae & $\beta$ & HICA & + & Influenza & - & + \\
\hline Neisseria gonorrhoeae & $\alpha$ & NgoCA & + & Gonorrhea & + & + \\
\hline Neisseria sicca & $\alpha$ & NsiCA & + & Septicemia & + & - \\
\hline \multirow{2}{*}{ Porphyromonas gingivalis $[11,13,55-57]$} & $\beta$ & PgiCA $\beta$ & \multirow[t]{2}{*}{+} & \multirow{2}{*}{$\begin{array}{c}\text { Periodontitis, } \\
\text { rheumatoid arthritis }\end{array}$} & + & + \\
\hline & $\gamma$ & PgiCA $\gamma$ & & & + & + \\
\hline \multirow{2}{*}{ Legionella pneumophila [42] } & $\beta$ & LpCA1 & \multirow[t]{2}{*}{+} & \multirow[t]{2}{*}{ Legionellosis } & + & + \\
\hline & $\beta$ & LpCA2 & & & + & + \\
\hline Clostridium perfringens [58] & $\beta$ & CpeCA & + & Food poisoning & - & + \\
\hline \multirow{2}{*}{ Brucella suis $[34,59,60]$} & $\beta$ & bsCA 1 & \multirow[t]{2}{*}{+} & \multirow[t]{2}{*}{ Brucellosis } & + & - \\
\hline & $\beta$ & BsCA II & & & + & - \\
\hline \multirow{2}{*}{ Burkholderia pseudomallei $[1,7,61]$} & $\beta$ & $\mathrm{BpsCA} \beta$ & \multirow[t]{2}{*}{+} & \multirow[t]{2}{*}{ Melioidosis } & - & + \\
\hline & $\gamma$ & $\mathrm{BpsCA} \gamma$ & & & + & + \\
\hline \multirow{2}{*}{ Salmonella enterica $[62,63]$} & $\beta$ & stCA 1 & \multirow[t]{2}{*}{+} & \multirow[t]{2}{*}{ Salmonellosis } & + & + \\
\hline & $\beta$ & stCA 2 & & & + & + \\
\hline Streptococcus pneumoniae [64] & $\beta$ & PCA & + & Pneumonia & + & + \\
\hline \multirow{3}{*}{ Mycobacterium tuberculosis [65-67] } & $\beta$ & mtCA 1 & \multirow[t]{3}{*}{+} & \multirow[t]{3}{*}{ Tuberculosis } & + & - \\
\hline & $\beta$ & mtCA 2 & & & + & - \\
\hline & $\beta$ & mtCA 3 & & & + & - \\
\hline Methanobacterium thermoautotrophicum [68] & $\beta$ & $\mathrm{Cab}$ & - & - & + & + \\
\hline \multirow{2}{*}{ Methanosarcina thermophila [69] } & $\gamma$ & Zn-Cam & - & - & + & + \\
\hline & $\gamma$ & Co-Cam & - & - & + & + \\
\hline Sulfurihydrogenibium yellowstonense $[19,70-72]$ & $\alpha$ & SspCA & - & - & + & + \\
\hline Sulfurihydrogenibium azorense [73-76] & $\alpha$ & SazCA & - & - & + & + \\
\hline Colwellia psychrerythraea $[10,38]$ & $\gamma$ & CpsCA & - & - & + & + \\
\hline Pseudoalteromonas haloplanktis $[77,78]$ & $\gamma$ & PhaCA $\gamma$ & - & - & + & + \\
\hline
\end{tabular}




\section{Results and Discussion}

\subsection{Purification and Protonographic Analysis}

The recombinant BpsCA $\beta$ was heterologously expressed as soluble protein in the cytoplasm of the E. coli (DE3) codon plus cells and produced as a fusion protein containing a His-tag tail at its N-terminal amino acid sequence. After sonication and centrifugation, BpsCA $\beta$ was purified from the cell extract using the His-select HF Nickel column as the affinity column. The fusion protein showed an apparent molecular weight of about $30 \mathrm{kDa}$, as indicated by sodium dodecyl sulfate (SDS)-polyacrylamide gel electrophoresis (PAGE) (SDS-PAGE, Figure 2A). The apparent molecular weight of $30 \mathrm{kDa}$ on the SDS-PAGE is due to the SDS concentration, which determines the separation of the subunits of the BpsCA $\beta$. Generally, $\beta$-CAs catalyze the hydration of carbon dioxide to bicarbonate and protons when the $\beta$-CAs monomers assemble into dimers, tetramers, or octamers. To investigate the hydratase activity of BpsCA $\beta$ and bCA (commercial $\alpha$-CA from bovine erythrocytes, purchased from Sigma) on the SDS-PAGE gel, samples of BpsCA $\beta$ or bCA were prepared and loaded on the gel. The protonography technique is based on the monitoring of $\mathrm{pH}$ variation in the gel due to the catalyzed conversion of $\mathrm{CO}_{2}$ to bicarbonate and protons. The production of hydrogen ions during the $\mathrm{CO}_{2}$ hydration reaction due to the bCA or $\mathrm{BpsCA} \beta$ hydratase activity lowers the $\mathrm{pH}$ of the solution until the color transition point of the dye (bromothymol blue) is reached (pH 6.8) [79-81]. This dye appears blue in its deprotonated form, while its color changes to yellow in the protonated form. The protonated form of bromothymol blue has its peak absorption at $692 \mathrm{~nm}$, thus reflecting yellow light in acidic solutions, and the deprotonated form has its peak absorption at $602 \mathrm{~nm}$, thus reflecting blue light in more basic solutions [79-81]. Figure 2 shows the results of the protonographic analysis, and the enzyme activity was detected as yellow bands against the blue background. The protonogram of BpsCA $\beta$ (Figure 2B) showed a $30 \mathrm{kDa}$ band of activity. As described in the literature, mammal $\alpha$-CAs are monomeric, and the protonogram of bCA showed a single band of activity corresponding to a monomer of $30 \mathrm{kDa}$. However, as mentioned previously, $\beta$-CAs are active enzymes for the $\mathrm{CO}_{2}$ hydratase reaction when assembled into dimers, tetramers, or octamers. The yellow bands found corresponding to the inactive monomeric form of $\mathrm{BpsCA} \beta$ is due to the fact that at the end of the electrophoretic run, the SDS is removed from the gel. This procedure may lead to the rearrangement of $\mathrm{BpsCA} \beta$ monomers in the gel, and the final result is the reconstitution of the active oligomeric forms of $\mathrm{BpsCA} \beta$.
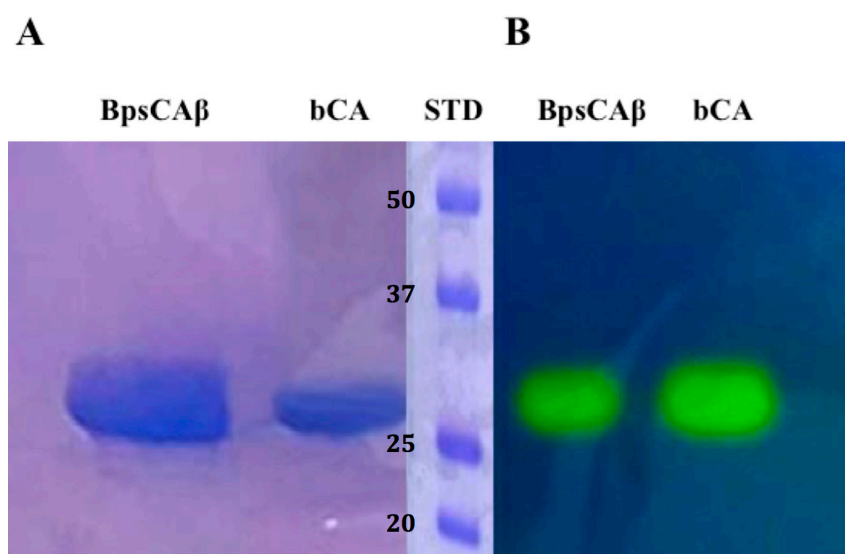

Figure 2. Comparison between SDS-PAGE and protonography of recombinant B. pseudomallei $\beta$-CA (BpsCA $\beta$ ). (A) SDS-PAGE of bCA and BpsCA $\beta$. The gel was stained with Coomassie blue; (B) Protonogram of $\alpha$-CA from bovine erythrocytes (bCA) and BpsCA $\beta$. The yellow bands on the blue background correspond to the bCA and BpsCA $\beta$ activity, which determine the drop of $\mathrm{pH}$ from 8.2 to the transition point of the dye ( $\mathrm{pH}$ 6.8). Yellow bands were obtained with an incubation time of $15 \mathrm{~s}$. STD: molecular markers starting from the top had the following molecular weights: $50 \mathrm{kDa}, 37 \mathrm{kDa}$, $25 \mathrm{kDA}$, and $20 \mathrm{kDa}$ (see bold numbers on the figure). 


\subsection{Kinetic Constants}

In Table 2 are shown the rate constants $\left(\mathrm{k}_{\mathrm{cat}}, \mathrm{K}_{\mathrm{M}}\right.$, and $\left.\mathrm{k}_{\mathrm{cat}} / \mathrm{K}_{\mathrm{M}}\right)$ of the BpsCA $\beta$ identified in the genome of Burkholderia pseudomallei and the inhibition constant $\left(\mathrm{K}_{\mathrm{I}}\right)$ using the inhibitor acetazolamide. These constants were compared with the kinetic parameters of the $\alpha$-CA from the Homo sapiens (isoforms hCA I and hCA II) and with those obtained from BpsCA $\gamma$ that were reported previously [7]. The catalytic activity values of these enzymes were determined using the "stopped-flow" technique. BpsCA $\beta$ showed a $\mathrm{k}_{\text {cat }}$ of $1.6 \times 10^{5} \mathrm{~s}^{-1}$ and a $\mathrm{k}_{\mathrm{cat}} / \mathrm{K}_{\mathrm{M}}$ of $3.4 \times 10^{7} \mathrm{M}^{-1} \cdot \mathrm{s}^{-1}$. It was slightly less active than the human isoform hCAI $\left(\mathrm{k}_{\mathrm{cat}}=2.0 \times 10^{5} \mathrm{~s}^{-1}\right)$. Interestingly, the $\gamma$-CA from B. pseudomallei showed a $\mathrm{k}_{\mathrm{cat}}=5.3 \times 10^{5} \mathrm{~s}^{-1}$, which is 3.3 times higher than the $\operatorname{BpsCA} \beta\left(\mathrm{k}_{\mathrm{cat}}=1.6 \times 10^{5} \mathrm{~s}^{-1}\right)$. This is also evident for the $\gamma$-CA from $V$. cholerae, which was 2.21 times more active than VchCA $\beta$ $\left(\mathrm{k}_{\mathrm{cat}}=7.39 \times 10^{5} \mathrm{~s}^{-1}\right)$. In addition, acetazolamide was found to be a less effective inhibitor for BpsCA $\beta$ $\left(\mathrm{K}_{\mathrm{I}}=\mathrm{X} \mathrm{nM}\right)$ and $\mathrm{BpsCA} \gamma\left(\mathrm{K}_{\mathrm{I}}=\mathrm{Y} \mathrm{nM}\right)[48-50]$ than for hCA II, VchCA $\alpha$, and hp $\beta C A$.

Table 2. Kinetic parameters for the $\mathrm{CO}_{2}$ hydration reaction catalysed by the human cytosolic isozymes hCA I and II ( $\alpha$-class CAs) at $20^{\circ} \mathrm{C}$ and pH 7.5 in $10 \mathrm{mM}$ HEPES buffer and $20 \mathrm{mM} \mathrm{Na}_{2} \mathrm{SO}_{4}, \beta$ - and $\gamma$-CAs from B. pseudomallei measured at $20^{\circ} \mathrm{C}$, pH 8.3 in $20 \mathrm{mM}$ TRIS buffer and $20 \mathrm{mM} \mathrm{NaClO}_{4}$ [82], $\alpha$-, $\beta$-, and $\gamma$-CAs from Vibrio cholerae $[8,49,50]$, and $\beta$-CA from Helicobacter pylori $[36,51,52]$. Acetazolamide inhibition data are also shown.

\begin{tabular}{cccccc}
\hline Enzyme & Activity Level & Class & $\mathbf{k}_{\mathbf{c a t}}\left(\mathbf{s}^{-\mathbf{1}}\right)$ & $\mathbf{k}_{\mathbf{c a t}} \mathbf{/} \mathbf{K}_{\mathbf{m}} \mathbf{( \mathbf { M } ^ { - \mathbf { 1 } } \cdot \mathbf { s } ^ { \mathbf { - 1 } } )}$ & $\mathbf{K}_{\mathbf{I}}$ (Acetazolamide) $(\mathbf{n M})$ \\
\hline hCA I & moderate & $\alpha$ & $2.0 \times 10^{5}$ & $5.0 \times 10^{7}$ & 250 \\
hCA II & very high & $\alpha$ & $1.4 \times 10^{6}$ & $1.5 \times 10^{8}$ & 12 \\
BpsCA $\beta$ & moderate & $\beta$ & $1.6 \times 10^{5}$ & $3.4 \times 10^{7}$ & 745 \\
BpsCA $\gamma$ & moderate & $\gamma$ & $5.3 \times 10^{5}$ & $2.5 \times 10^{7}$ & 149 \\
VchCA $\alpha$ & high & $\alpha$ & $8.23 \times 10^{5}$ & $7.0 \times 10^{7}$ & 6.8 \\
VchCA $\beta$ & moderate & $\beta$ & $3.34 \times 10^{5}$ & $4.1 \times 10^{7}$ & 451 \\
VchCA $\gamma$ & high & $\gamma$ & $7.39 \times 10^{5}$ & $6.4 \times 10^{7}$ & 473 \\
hp $\beta$ CA & high & $\beta$ & $7.1 \times 10^{5}$ & $4.8 \times 10^{7}$ & 40 \\
\hline
\end{tabular}

\subsection{Sulfonamides and Sulfamates Inhibition Profiles}

A panel of simple aromatic and heteroaromatic sulfonamides of types 1-24 and clinically used derivatives such as AAZ-HCT (Figure 1) was used to investigate the sulfonamide/sulfamate inhibition profile of BpsCA $\beta$. Acetazolamide (AAZ), methazolamide (MZA), ethoxzolamide (EZA), and dichlorophenamide (DCP) are the classical systemically acting CAIs [51-59]. Dorzolamide (DZA) and brinzolamide (BRZ) are topically-acting anti-glaucoma agents; benzolamide (BZA) is an orphan drug belonging to this class of pharmacological agents; whereas topiramate (TPM), zonisamide (ZNS), and sulthiame (SLT) are widely used antiepileptic drugs [60-65]. Sulpiride (SLP), indisulam (IND), valdecoxib (VLX), celecoxib (CLX), and hydrochlorothiazide (HCT) were shown by these groups to belong to this class of pharmacological agents, acting as efficient inhibitors against many enzymes from mammals, plants, and microorganisms such as bacteria, protozoa, and fungi [66-79]. Sulfonamides 1-24 and the clinically used agents investigated in this study were either commercially available or were prepared as reported earlier by our group [21,25,42].

Inhibition data with the 39 investigated sulfonamides/sulfamates against the two enzymes from B. pseudomallei BpsCA $\beta$ and BpsCA $\gamma$, as well as the human main isoforms hCA I and II (as possible off targets) are shown in Table 3. The following structure-activity relationship (SAR) can be drawn from the data of this table:

(i) Some sulfonamides, including 1, 4, 6-9, 18, 19, 24, SLP, VLX, CLX, SLT, and the sulfamate TPM did not inhibit BpsCA $\beta$ significantly up to $50 \mu \mathrm{M}$ concentration of inhibitor within the assay system (Table 3). They include a variety of chemotypes, such as simple benzenesulfonamides with compact meta- or para-substituents $(\mathbf{1}, \mathbf{4}, \mathbf{6}, \mathbf{1 8})$, halogen sulfanilamides (7-9), the compounds with elongated molecules 19 and 24 , as well as the clinically used compounds with a rather bulky 
scaffold such as the two coxibs, sulpiride and the sugar sulfamate TPM. It is thus difficult to draw a precise SAR for this limited number of inhibitors with such diverse structural features in their molecules.

(ii) A large number of the investigated sulfonamides were moderately potent inhibitors of $\mathrm{BpsCA} \beta$, with inhibition constants in the micromolar range. They include: 2, 3, 5, 10, 13-16, 21-23, EZA, DZA, BRZ, ZNS, IND, and HCT (Table 3), and their $\mathrm{K}_{\mathrm{I}}$ range between 1500 and $5200 \mathrm{nM}$. Several interesting SAR data can be observed: the shift of the amino moiety from meta (as in 1) to para (as in 2) led to a net increase in the inhibitory action, as sulfanilamide $\mathbf{2}$ is moderately potent whereas metanilamide 1 was devoid of activity. The same activity was shown by 5 , which has an extra methylene moiety compared to sulfanilamide, but the increase of the linker to two methylene groups (as in 6) leads to the complete loss of activity. It is also interesting to note that the introduction of halogens in the sulfanilamide 2 scaffold (as in 7-9) led to a loss of activity against $\mathrm{BpsCA} \beta$, although the halogenated sulfonamides were more effective hCA I and II inhibitors compared to sulfanilamide itself (Table 3). For the phenol/alcohols 15-17 on the other hand, the increase of the linker between the $\mathrm{OH}$ moiety and the aromatic ring from 0 to 2 led to an increase of the BpsCA $\beta$ inhibitory action, with the best inhibitor being the hydroxyethyl derivative $17\left(\mathrm{~K}_{\mathrm{I}}\right.$ of $\left.417 \mathrm{nM}\right)$. However, for the similar subseries 22-24, the SAR is more complex, with 23 acting as the best inhibitor and the shorter or the longer molecule congeners (22 and 24) showing a decrease (or a loss) of activity (Table 3). The bulky clinically used derivatives EZA, DZA, BRZ, ZNS, IND, and HCT also belong to this category of CAIs with medium potency inhibitory action against $\mathrm{BpsCA} \beta$

(iii) The most efficient BpsCA $\beta$ inhibitors detected among the investigated sulfonamides were 11, 12, and DCP (belonging to the benzene-1,3-disulfonamide class of compounds), $\mathbf{1 7}$ (already mentioned above), 20, and BZA (benzolamide-type CAIs possessing an elongated molecule and two sulfonamide functionalities), AAZ, and MZA. These sulfonamides showed $\mathrm{K}_{\mathrm{I}}$ in the range of 185-745 $\mathrm{nM}$ (Table 3). The following SAR is obvious: the deacetylated derivatives of AAZ (13) and MZA (14) were much less effective BpsCA $\beta$ inhibitors compared to the clinically used drugs. This is a general phenomenon seen for many other CAs investigated earlier [65-79]. The best BpsCA $\beta$ inhibitors were MZA and BZA, with an almost identical inhibition constant (185-186 nM). It is interesting to note that MZA-which differs only by a $\mathrm{CH}_{2}$ moiety from AAZ - was four times stronger as an inhibitor than acetazolamide. Considering benzolamide (BZA), the introduction of a 4-amino moiety as in aminobenzolamide (20), led to a small decrease of the inhibitory activity from $185 \mathrm{nM}$ to $266 \mathrm{nM}$ (Table 3). Such compounds belong to a class of disulfonamide CAIs, which are highly effective against many CAs [80]. As mentioned above, the same efficient inhibitory action was observed for the benzene-1,3-disulfonamides DCP, 11, and 12, which incorporate two primary sulfonamide moieties in their scaffolds. Overall, the main conclusion is that several important CAI scaffolds lead to effective BpsCA $\beta$ inhibition, but compounds with an inhibition constant $<100 \mathrm{nM}$ were not identified in this study.

(iv) The inhibition profile of $\mathrm{BpsCA} \beta$ differs substantially from that of the $\gamma$-class enzyme from the same pathogen (BpsCA $\gamma$ ) that was recently investigated by this group [7]. A relatively limited number of sulfonamides that have been investigated act as effective CAIs against both the $\beta$ - and $\gamma$-CAs from this bacterium (Table 3). Among them are 20, AAZ, MZA, and BZA, with the latter compound having the most promising profile ( $\mathrm{K}_{\mathrm{I}}$ of 653 and $185 \mathrm{nM}$, respectively). Thus, BZA might be considered an important lead compound for obtaining more effective CAIs targeting Burkholderia pseudomallei. 
Table 3. Sulfonamides/sulfamates inhibition constants $\left(\mathrm{K}_{\mathrm{I}}, \mathrm{nM}\right)$ for the human $\alpha$-CAs (isoforms hCA I and II) and the $\beta-/ \gamma$-CAs identified in the genome of B. pseudomallei, assayed by a $\mathrm{CO}_{2}$ hydrase stopped flow method $[7,50]$.

\begin{tabular}{|c|c|c|c|c|}
\hline \multirow{2}{*}{ Inhibitor } & \multicolumn{4}{|c|}{$\mathrm{K}_{\mathrm{I}}, \mathrm{nM}^{*}$} \\
\hline & hCA I & hCA II & $\mathrm{BpsCA} \gamma$ & BpsCA $\beta$ \\
\hline 1 & 45,400 & 295 & 574 & $>50,000$ \\
\hline 2 & 25,000 & 240 & 1720 & 3895 \\
\hline 3 & 28,000 & 300 & 1550 & 3170 \\
\hline 4 & 78,500 & 320 & $>50,000$ & $>50,000$ \\
\hline 5 & 25,000 & 170 & $>50,000$ & 3900 \\
\hline 6 & 21,000 & 160 & $>50,000$ & $>50,000$ \\
\hline 7 & 8300 & 60 & $>50,000$ & $>50,000$ \\
\hline 8 & 9800 & 110 & 12,500 & $>50,000$ \\
\hline 9 & 6500 & 40 & $>50,000$ & $>50,000$ \\
\hline 10 & 6000 & 70 & $>50,000$ & 4100 \\
\hline 11 & 5800 & 63 & 14,000 & 425 \\
\hline 12 & 8400 & 75 & 23,500 & 307 \\
\hline 13 & 8600 & 60 & 18,400 & 3065 \\
\hline 14 & 9300 & 19 & 1810 & 2500 \\
\hline 15 & 6 & 2 & 9650 & 4345 \\
\hline 16 & 164 & 46 & 10,800 & 2215 \\
\hline 17 & 185 & 50 & 1825 & 417 \\
\hline 18 & 109 & 33 & 1500 & $>50000$ \\
\hline 19 & 95 & 30 & 1838 & $>50000$ \\
\hline 20 & 690 & 12 & 1810 & 266 \\
\hline 21 & 55 & 80 & 1335 & 1650 \\
\hline 22 & 21,000 & 125 & 1805 & 5200 \\
\hline 23 & 23,000 & 133 & 1700 & 1500 \\
\hline 24 & 24,000 & 125 & 24,500 & $>50,000$ \\
\hline AAZ & 250 & 12 & 149 & 745 \\
\hline MZA & 50 & 14 & 1595 & 186 \\
\hline EZA & 25 & 8 & 1865 & 3850 \\
\hline DCP & 1200 & 38 & $>50,000$ & 529 \\
\hline DZA & 50,000 & 9 & 2260 & 3670 \\
\hline BRZ & 45,000 & 3 & 1270 & 4270 \\
\hline BZA & 15 & 9 & 653 & 185 \\
\hline TPM & 250 & 10 & 3010 & $>50,000$ \\
\hline ZNS & 56 & 35 & $>50,000$ & 4060 \\
\hline SLP & 1200 & 40 & 5600 & $>50,000$ \\
\hline IND & 31 & 15 & 1800 & 4375 \\
\hline VLX & $>50,000$ & 43 & $>50,000$ & $>50,000$ \\
\hline CLX & 50,000 & 21 & $>50,000$ & $>50,000$ \\
\hline SLT & 374 & 9 & 8900 & $>50,000$ \\
\hline HCT & 328 & 290 & $>50,000$ & 3490 \\
\hline
\end{tabular}

${ }^{*}$ Mean from three different assays. Errors in the range of $\pm 10 \%$ of the reported values (data not shown).

\section{Materials and Methods}

\subsection{Gene Identification and Cloning}

The identification of the gene encoding B. pseudomallei $\beta$-CA (BpsCA $\beta)$ was performed as described by Del Prete et al. [61] Briefly, the $\beta$-CA gene of B. pseudomallei with the accession number WP_004189176.1 was identified running the "BLAST" program, using the nucleotide sequences of bacterial $\beta$-CAs as query sequence. The GeneArt Company (Invitrogen) - specializing in gene synthesis-designed the synthetic BpsCA $\beta$ gene (BpsCA $\beta$-DNA) encoding for the BpsCA $\beta$ (protein of 256 amino acid residues) containing four base-pair sequences (CACC) necessary for directional cloning 
at the $5^{\prime}$ end of the PfCAdom gene. The recovered PfCAdom gene and the linearized expression vector (pET-100/D-TOPO) were ligated by T4 DNA ligase to form the expression vector $\mathrm{pET}-100 / \mathrm{BpsCA} \beta$.

\subsection{Expression and Purification of the Recombinant $B p s C A \beta$}

BL21-CodonPlus(DE3)-RIPL competent cells (Agilent) were transformed with pET-100/BpsCA $\beta$, grown at $37^{\circ} \mathrm{C}$, and induced with $1 \mathrm{mM}$ isopropil- $\beta$-D-1-tiogalattopiranoside (IPTG). After $30 \mathrm{~min}$, $\mathrm{ZnSO}_{4}(0.5 \mathrm{mM})$ was added to the culture medium and cells were grown for an additional $3 \mathrm{~h}$. Subsequently, cells were harvested and re-suspended in the following buffer: $50 \mathrm{mM}$ Tris/ $\mathrm{HCl}, \mathrm{pH} 8.0$, $0.5 \mathrm{mM}$ phenylmethylsulfonyl fluoride (PMSF), and $1 \mathrm{mM}$ benzamidine. Cells were then disrupted by sonication at $4{ }^{\circ} \mathrm{C}$. After centrifugation at $12,000 \times \mathrm{g}$ for $45 \mathrm{~min}$, the supernatant was incubated with His Select HF nickel affinity gel resin (Sigma) equilibrated in lysis buffer for $30 \mathrm{~min}$. Following centrifugation at $2000 \times g$, the resin was washed in buffer $(50 \mathrm{mM}$ Tris $/ \mathrm{HCl}, \mathrm{pH} 8.3,500 \mathrm{mM} \mathrm{KCl}$, $20 \mathrm{mM}$ imidazole). The protein was eluted with the wash buffer containing $300 \mathrm{mM}$ imidazole. The collected fractions were dialyzed against $50 \mathrm{mM}$ Tris $/ \mathrm{HCl}, \mathrm{pH}$ 8.3. At this stage of purification, the protein was at least $95 \%$ pure and the obtained recovery was of about $20 \mathrm{mg}$ of the recombinant protein.

\subsection{Protonography}

Sodium dodecyl sulfate (SDS)-polyacrylamide gel electrophoresis (PAGE) was performed as described by Laemmli [83]. Wells of $12 \%$ SDS-gel were loaded with bCA or BpsCA $\beta$ mixed with Laemmli loading buffer without 2-mercaptoethanol and without boiling the samples in order to avoid protein denaturation. The gel was run at $180 \mathrm{~V}$ until the dye front ran off the gel. Following the electrophoresis, the gel was removed from glass plates and soaked in 2.5\% Triton X-100 for $1 \mathrm{~h}$ on a shaker and then twice in $100 \mathrm{mM}$ Tris, pH 8.2 containing 10\% isopropanol for $10 \mathrm{~min}$. Subsequently, the gel was incubated in $0.1 \%$ bromothymol blue in $100 \mathrm{mM}$ Tris, $\mathrm{pH} 8.2$ for $30 \mathrm{~min}$ and then immersed in $\mathrm{CO}_{2}$-saturated $\mathrm{ddH}_{2} \mathrm{O}$ to visualize the hydratase activity of the enzyme. The assay was performed at room temperature and the $\mathrm{CO}_{2}$-saturated solution was prepared by bubbling $\mathrm{CO}_{2}$ into $200 \mathrm{~mL}$ distilled water for approximately $3 \mathrm{~h}$. The local decrease in $\mathrm{pH}$ due to the presence of CA activity was evidenced by the formation of yellow bands due to the change of the indicator color from blue (alkaline $\mathrm{pH}$ ) to yellow (acidic $\mathrm{pH}$ ) [79-81].

\subsection{Kinetic and Inhibition Assay}

An Applied Photophysics stopped-flow instrument has been used for assaying the CA-catalyzed $\mathrm{CO}_{2}$ hydration activity. [82] Phenol red (at a concentration of $0.2 \mathrm{mM}$ ) was used as indicator, working at the absorbance maximum of $557 \mathrm{~nm}$, with $20 \mathrm{mM}$ TRIS (pH 8.3) as buffer, and $20 \mathrm{mM} \mathrm{NaClO}_{4}$ (for maintaining constant the ionic strength), following the initial rates of the CA-catalyzed $\mathrm{CO}_{2}$ hydration reaction for a period of $10-100 \mathrm{~s}$. The $\mathrm{CO}_{2}$ concentrations ranged from 1.7 to $17 \mathrm{mM}$ for the determination of the kinetic parameters (by Lineweaver-Burk plots) and inhibition constants. For each inhibitor, at least six traces of the initial $5 \%-10 \%$ of the reaction were used to determine the initial velocity. The uncatalyzed rates were determined in the same manner and subtracted from the total observed rates. Stock solutions of inhibitor (10-100 $\mathrm{mM}$ ) were prepared in distilled-deionized water, and dilutions up to $0.01 \mathrm{mM}$ were done thereafter with the assay buffer. Inhibitor and enzyme solutions were preincubated together for $15 \mathrm{~min}$ at room temperature prior to assay in order to allow for the formation of the E-I (Enzyme-Inhibitor) complex or for the eventual active site-mediated hydrolysis of the inhibitor. The inhibition constants were obtained by non-linear least-squares methods using PRISM 3 and the Cheng-Prusoff equation (as reported earlier), and represent the mean from at least three different determinations. All CA isoforms were recombinant ones obtained in-house. All salts/small molecules were of the highest purity available, from Sigma-Aldrich (Milan, Italy). 


\section{Conclusions}

We have cloned, purified, and characterized a $\beta$-CA from the pathogenic bacterium Burkholderia pseudomallei, responsible for the tropical disease melioidosis, named here BpsCA $\beta$. The enzyme showed a relatively high catalytic activity for the physiologic $\mathrm{CO}_{2}$ hydration reaction to bicarbonate and protons, with the following kinetic parameters: $\mathrm{k}_{\text {cat }}$ of $1.6 \times 10^{5} \mathrm{~s}^{-1}$ and $\mathrm{k}_{\text {cat }} / \mathrm{K}_{\mathrm{M}}$ of $3.4 \times 10^{7} \mathrm{M}^{-1} \cdot \mathrm{s}^{-1}$. An inhibition study with a panel of 38 sulfonamides and one sulfamate-including many agents that are used clinically_revealed an interesting structure-activity relationship for the interaction of this enzyme with its inhibitors. Many simple sulfonamides and clinically used agents such as topiramate, sulpiride, celecoxib, valdecoxib, and sulthiame were ineffective BpsCA $\beta$ inhibitors $\left(\mathrm{K}_{\mathrm{I}}>50 \mu \mathrm{M}\right)$. Other drugs, such as ethoxzolamide, dorzolamide, brinzolamide, zonisamide, indisulam, and hydrochlorothiazide were moderately potent micromolar inhibitors. The most promising inhibition was observed using benzene-1,3-disulfonamides, benzolamide and its analogs, acetazolamide, and methazolamide, which showed $\mathrm{K}_{\mathrm{I}}$ in the range of $185-745 \mathrm{nM}$. The inhibition profile of $\mathrm{BpsCA} \beta$ differs substantially from that of the $\gamma$-class enzyme from the same pathogen (BpsCA $\gamma$ ), making it rather difficult to propose compounds that would effectively interact with both enzymes. However, benzolamide was one of the most promising inhibitors of both these CAs, with $\mathrm{K}_{\mathrm{I}}$ of 653 and $185 \mathrm{nM}$, respectively. Thus, benzolamide is an interesting lead compound for the design of more effective such agents, which may be useful tools for understanding the pathogenicity of this bacterium.

Acknowledgments: We acknowledge the Australian Research Council for funding (DP160102681).

Author Contributions: Daniela Vullo performed the enzyme kinetic and all the inhibition assays; Sonia Del Prete, Vincenzo Carginale and Pietro Di Fonzo performed the cloning, expression, purification and protonography of the recombinant bacterial enzyme; W. Alexander Donald edited and revised the English of the manuscript; Clemente Capasso and Claudiu T. Supuran wrote, edited and supervised the manuscript.

Conflicts of Interest: The authors declare no conflict of interest.

\section{References}

1. Vullo, D.; del Prete, S.; Osman, S.M.; AlOthman, Z.; Capasso, C.; Donald, W.A.; Supuran, C.T. Burkholderia pseudomallei $\gamma$-carbonic anhydrase is strongly activated by amino acids and amines. Bioorg. Med. Chem. Lett. 2017, 27, 77-80. [CrossRef] [PubMed]

2. Vullo, D.; del Prete, S.; de Luca, V.; Carginale, V.; Ferraroni, M.; Dedeoglu, N.; Osman, S.M.; AlOthman, Z.; Capasso, C.; Supuran, C.T. Anion inhibition studies of the $\beta$-carbonic anhydrase from the pathogenic bacterium Vibrio cholerae. Bioorg. Med. Chem. Lett. 2016, 26, 1406-1410. [CrossRef] [PubMed]

3. Vullo, D.; del Prete, S.; Capasso, C.; Supuran, C.T. Carbonic anhydrase activators: Activation of the $\beta$-carbonic anhydrase from Malassezia globosa with amines and amino acids. Bioorg. Med. Chem. Lett. 2016, 26, 1381-1385. [CrossRef] [PubMed]

4. Supuran, C.T.; Capasso, C. New light on bacterial carbonic anhydrases phylogeny based on the analysis of signal peptide sequences. J. Enzym. Inhib. Med. Chem. 2016, 31, 1254-1260. [CrossRef] [PubMed]

5. Ozensoy Guler, O.; Capasso, C.; Supuran, C.T. A magnificent enzyme superfamily: Carbonic anhydrases, their purification and characterization. J. Enzym. Inhib. Med. Chem. 2016, 31, 689-694. [CrossRef] [PubMed]

6. Melis, C.; Meleddu, R.; Angeli, A.; Distinto, S.; Bianco, G.; Capasso, C.; Cottiglia, F.; Angius, R.; Supuran, C.T.; Maccioni, E. Isatin: A privileged scaffold for the design of carbonic anhydrase inhibitors. J. Enzym. Inhib. Med. Chem. 2017, 32, 68-73. [CrossRef] [PubMed]

7. Del Prete, S.; Vullo, D.; di Fonzo, P.; Osman, S.M.; AlOthman, Z.; Donald, W.A.; Supuran, C.T.; Capasso, C. Sulfonamide inhibition profile of the $\gamma$-carbonic anhydrase identified in the genome of the pathogenic bacterium Burkholderia pseudomallei the etiological agent responsible of melioidosis. Bioorg. Med. Chem. Lett. 2017, 27, 490-495. [CrossRef] [PubMed]

8. Del Prete, S.; Vullo, D.; de Luca, V.; Carginale, V.; di Fonzo, P.; Osman, S.M.; AlOthman, Z.; Supuran, C.T.; Capasso, C. Anion inhibition profiles of $\alpha-, \beta$ - and $\gamma$-carbonic anhydrases from the pathogenic bacterium Vibrio cholerae. Bioorg. Med. Chem. 2016, 24, 3413-3417. [CrossRef] [PubMed] 
9. Del Prete, S.; de Luca, V.; Vullo, D.; Osman, S.M.; AlOthman, Z.; Carginale, V.; Supuran, C.T.; Capasso, C. A new procedure for the cloning, expression and purification of the $\beta$-carbonic anhydrase from the pathogenic yeast Malassezia globosa, an anti-dandruff drug target. J. Enzym. Inhib. Med. Chem. 2016, 31, 1156-1161. [CrossRef] [PubMed]

10. De Luca, V.; Vullo, D.; del Prete, S.; Carginale, V.; Osman, S.M.; AlOthman, Z.; Supuran, C.T.; Capasso, C. Cloning, characterization and anion inhibition studies of a $\gamma$-carbonic anhydrase from the antarctic bacterium Colwellia psychrerythraea. Bioorg. Med. Chem. 2016, 24, 835-840. [CrossRef] [PubMed]

11. Capasso, C.; Supuran, C.T. An overview of the carbonic anhydrases from two pathogens of the oral cavity: Streptococcus mutans and Porphyromonas gingivalis. Curr. Top. Med. Chem. 2016, 16, 2359-2368. [CrossRef] [PubMed]

12. Supuran, C.T.; Capasso, C. The $\eta$-class carbonic anhydrases as drug targets for antimalarial agents. Expert Opin. Ther. Targets 2015, 19, 551-563. [CrossRef] [PubMed]

13. Del Prete, S.; Vullo, D.; de Luca, V.; AlOthman, Z.; Osman, S.M.; Supuran, C.T.; Capasso, C. Biochemical characterization of recombinant $\beta$-carbonic anhydrase (PgiCAb) identified in the genome of the oral pathogenic bacterium Porphyromonas gingivalis. J. Enzym. Inhib. Med. Chem. 2015, 30, 366-370. [CrossRef] [PubMed]

14. Pinard, M.A.; Lotlikar, S.R.; Boone, C.D.; Vullo, D.; Supuran, C.T.; Patrauchan, M.A.; McKenna, R. Structure and inhibition studies of a type II $\beta$-carbonic anhydrase psCA3 from Pseudomonas aeruginosa. Bioorg. Med. Chem. 2015, 23, 4831-4838. [CrossRef] [PubMed]

15. Ferraroni, M.; del Prete, S.; Vullo, D.; Capasso, C.; Supuran, C.T. Crystal structure and kinetic studies of a tetrameric type II $\beta$-carbonic anhydrase from the pathogenic bacterium Vibrio cholerae. Acta Crystallogr. D Biol. Crystallogr. 2015, 71, 2449-2456. [CrossRef] [PubMed]

16. De Simone, G.; Monti, S.M.; Alterio, V.; Buonanno, M.; de Luca, V.; Rossi, M.; Carginale, V.; Supuran, C.T.; Capasso, C.; di Fiore, A. Crystal structure of the most catalytically effective carbonic anhydrase enzyme known, sazca from the thermophilic bacterium Sulfurihydrogenibium azorense. Bioorg. Med. Chem. Lett. 2015, 25, 2002-2006. [CrossRef] [PubMed]

17. Zolnowska, B.; Slawinski, J.; Pogorzelska, A.; Chojnacki, J.; Vullo, D.; Supuran, C.T. Carbonic anhydrase inhibitors. Synthesis, and molecular structure of novel series $N$-substituted $N^{\prime}$-(2-arylmethylthio-4-chloro-5methylbenzenesulfonyl)guanidines and their inhibition of human cytosolic isozymes I and II and the transmembrane tumor-associated isozymes IX and XII. Eur. J. Med. Chem. 2014, 71, 135-147. [PubMed]

18. De Luca, L.; Ferro, S.; Damiano, F.M.; Supuran, C.T.; Vullo, D.; Chimirri, A.; Gitto, R. Structure-based screening for the discovery of new carbonic anhydrase VII inhibitors. Eur. J. Med. Chem. 2014, 71, 105-111. [CrossRef] [PubMed]

19. Di Fiore, A.; Capasso, C.; de Luca, V.; Monti, S.M.; Carginale, V.; Supuran, C.T.; Scozzafava, A.; Pedone, C.; Rossi, M.; de Simone, G. X-ray structure of the first "extremo- $\alpha$-carbonic anhydrase", a dimeric enzyme from the thermophilic bacterium Sulfurihydrogenibium yellowstonense YO3AOP1. Acta Crystallogr. D Biol. Crystallogr. 2013, 69, 1150-1159. [CrossRef] [PubMed]

20. Supuran, C.T. Structure-based drug discovery of carbonic anhydrase inhibitors. J. Enzym. Inhib. Med. Chem. 2012, 27, 759-772. [CrossRef] [PubMed]

21. Supuran, C.T. Carbonic anhydrases-An overview. Curr. Pharm. Des. 2008, 14, 603-614. [CrossRef] [PubMed]

22. Supuran, C.T. Advances in structure-based drug discovery of carbonic anhydrase inhibitors. Expert Opin. Drug Discov. 2017, 12, 61-88. [CrossRef] [PubMed]

23. Bhatt, A.; Mahon, B.P.; Cruzeiro, V.W.; Cornelio, B.; Laronze-Cochard, M.; Ceruso, M.; Sapi, J.; Rance, G.A.; Khlobystov, A.N.; Fontana, A.; et al. Structure-activity relationships of benzenesulfonamide-based inhibitors towards carbonic anhydrase isoform specificity. Chembiochem 2017, 18, 213-222. [CrossRef] [PubMed]

24. Alterio, V.; Langella, E.; Viparelli, F.; Vullo, D.; Ascione, G.; Dathan, N.A.; Morel, F.M.; Supuran, C.T.; de Simone, G.; Monti, S.M. Structural and inhibition insights into carbonic anhydrase CDCA1 from the marine diatom Thalassiosira weissflogii. Biochimie 2012, 94, 1232-1241. [CrossRef] [PubMed]

25. Supuran, C.T. Structure and function of carbonic anhydrases. Biochem. J. 2016, 473, 2023-2032. [CrossRef] [PubMed]

26. Buzas, G.M.; Supuran, C.T. The history and rationale of using carbonic anhydrase inhibitors in the treatment of peptic ulcers. In memoriam ioan puscas (1932-2015). J. Enzym. Inhib. Med. Chem. 2016, 31, 527-533. [CrossRef] [PubMed] 
27. Capasso, C.; Supuran, C.T. An overview of the selectivity and efficiency of the bacterial carbonic anhydrase inhibitors. Curr. Med. Chem. 2015, 22, 2130-2139. [CrossRef] [PubMed]

28. Carta, F.; Supuran, C.T.; Scozzafava, A. Sulfonamides and their isosters as carbonic anhydrase inhibitors. Future Med. Chem. 2014, 6, 1149-1165. [CrossRef] [PubMed]

29. Capasso, C.; Supuran, C.T. An overview of the $\alpha-, \beta$ - and $\gamma$-carbonic anhydrases from bacteria: Can bacterial carbonic anhydrases shed new light on evolution of bacteria? J. Enzym. Inhib. Med. Chem. 2015, 30, 325-332. [CrossRef] [PubMed]

30. Supuran, C.T. Carbonic anhydrases: Novel therapeutic applications for inhibitors and activators. Nat. Rev. Drug Discov. 2008, 7, 168-181. [CrossRef] [PubMed]

31. Capasso, C.; Supuran, C.T. Bacterial, fungal and protozoan carbonic anhydrases as drug targets. Expert Opin. Ther. Targets 2015, 19, 1689-1704. [CrossRef] [PubMed]

32. Capasso, C.; Supuran, C.T. Sulfa and trimethoprim-like drugs-Antimetabolites acting as carbonic anhydrase, dihydropteroate synthase and dihydrofolate reductase inhibitors. J. Enzym. Inhib. Med. Chem. 2014, 29, 379-387. [CrossRef] [PubMed]

33. Capasso, C.; Supuran, C.T. Anti-infective carbonic anhydrase inhibitors: A patent and literature review. Expert Opin. Ther. Pat. 2013, 23, 693-704. [CrossRef] [PubMed]

34. Joseph, P.; Ouahrani-Bettache, S.; Montero, J.L.; Nishimori, I.; Minakuchi, T.; Vullo, D.; Scozzafava, A.; Winum, J.Y.; Kohler, S.; Supuran, C.T. A new $\beta$-carbonic anhydrase from Brucella suis, its cloning, characterization, and inhibition with sulfonamides and sulfamates, leading to impaired pathogen growth. Bioorg. Med. Chem. 2011, 19, 1172-1178. [CrossRef] [PubMed]

35. Modak, J.K.; Liu, Y.C.; Machuca, M.A.; Supuran, C.T.; Roujeinikova, A. Structural basis for the inhibition of Helicobacter pylori $\alpha$-carbonic anhydrase by sulfonamides. PLoS ONE 2015, 10, e0127149. [CrossRef] [PubMed]

36. Nishimori, I.; Onishi, S.; Takeuchi, H.; Supuran, C.T. The $\alpha$ and $\beta$ classes carbonic anhydrases from Helicobacter pylori as novel drug targets. Curr. Pharm. Des. 2008, 14, 622-630. [PubMed]

37. Nishimori, I.; Vullo, D.; Minakuchi, T.; Morimoto, K.; Onishi, S.; Scozzafava, A.; Supuran, C.T. Carbonic anhydrase inhibitors: Cloning and sulfonamide inhibition studies of a carboxyterminal truncated $\alpha$-carbonic anhydrase from Helicobacter pylori. Bioorg. Med. Chem. Lett. 2006, 16, 2182-2188. [CrossRef] [PubMed]

38. Vullo, D.; De Luca, V.; Del Prete, S.; Carginale, V.; Scozzafava, A.; Osman, S.M.; AlOthman, Z.; Capasso, C.; Supuran, C.T. Sulfonamide inhibition studies of the $\gamma$-carbonic anhydrase from the antarctic bacterium Colwellia psychrerythraea. Bioorg. Med. Chem. Lett. 2016, 26, 1253-1259. [CrossRef] [PubMed]

39. Del Prete, S.; Isik, S.; Vullo, D.; de Luca, V.; Carginale, V.; Scozzafava, A.; Supuran, C.T.; Capasso, C. DNA cloning, characterization, and inhibition studies of an $\alpha$-carbonic anhydrase from the pathogenic bacterium Vibrio cholerae. J. Med. Chem. 2012, 55, 10742-10748. [CrossRef] [PubMed]

40. Supuran, C.T. Carbonic anhydrases: From biomedical applications of the inhibitors and activators to biotechnological use for $\mathrm{CO}_{2}$ capture. J. Enzym. Inhib. Med. Chem. 2013, 28, 229-230. [CrossRef] [PubMed]

41. Capasso, C.; Supuran, C. Inhibition of bacterial carbonic anhydrases as a novel approach to escape drug resistance. Curr. Top. Med. Chem. 2017, 17, 1237-1248.

42. Supuran, C.T. Legionella pneumophila carbonic anhydrases: Underexplored antibacterial drug targets. Pathogens 2016, 5, 44. [CrossRef] [PubMed]

43. Supuran, C.T. How many carbonic anhydrase inhibition mechanisms exist? J. Enzym. Inhib. Med. Chem. 2016, 31, 345-360. [CrossRef] [PubMed]

44. Bejaoui, M.; Pantazi, E.; de Luca, V.; Panisello, A.; Folch-Puy, E.; Hotter, G.; Capasso, C.; Supuran, C.T.; Rosello-Catafau, J. Correction: Carbonic anhydrase protects fatty liver grafts against ischemic reperfusion damage. PLoS ONE 2015, 10, e0139411. [CrossRef] [PubMed]

45. De Simone, G.; Supuran, C.T. (In)organic anions as carbonic anhydrase inhibitors. J. Inorg. Biochem. 2012, 111, 117-129. [CrossRef] [PubMed]

46. Supuran, C.T. Bacterial carbonic anhydrases as drug targets: Toward novel antibiotics? Front Pharmacol 2011, 2, 34. [CrossRef] [PubMed]

47. Stephens, D.P.; Thomas, J.H.; Ward, L.M.; Currie, B.J. Melioidosis causing critical illness: A review of 24 years of experience from the royal darwin hospital ICU. Crit. Care Med. 2016, 44, 1500-1505. [CrossRef] [PubMed] 
48. Gilad, J.; Schwartz, D.; Amsalem, Y. Clinical features and laboratory diagnosis of infection with the potential bioterrorism agents burkholderia mallei and Burkholderia pseudomallei. Int. J. Biomed. Sci. 2007, 3, 144-152. [PubMed]

49. Del Prete, S.; Vullo, D.; de Luca, V.; Carginale, V.; Osman, S.M.; AlOthman, Z.; Supuran, C.T.; Capasso, C. Comparison of the sulfonamide inhibition profiles of the $\alpha-, \beta$ - and $\gamma$-carbonic anhydrases from the pathogenic bacterium Vibrio cholerae. Bioorg. Med. Chem. Lett. 2016, 26, 1941-1946. [CrossRef] [PubMed]

50. Del Prete, S.; Vullo, D.; de Luca, V.; Carginale, V.; Ferraroni, M.; Osman, S.M.; AlOthman, Z.; Supuran, C.T.; Capasso, C. Sulfonamide inhibition studies of the $\beta$-carbonic anhydrase from the pathogenic bacterium Vibrio cholerae. Bioorg. Med. Chem. 2016, 24, 1115-1120. [CrossRef] [PubMed]

51. Modak, J.K.; Liu, Y.C.; Supuran, C.T.; Roujeinikova, A. Structure-activity relationship for sulfonamide inhibition of Helicobacter pylori $\alpha$-carbonic anhydrase. J. Med. Chem. 2016, 59, 11098-11109. [CrossRef] [PubMed]

52. Morishita, S.; Nishimori, I.; Minakuchi, T.; Onishi, S.; Takeuchi, H.; Sugiura, T.; Vullo, D.; Scozzafava, A.; Supuran, C.T. Cloning, polymorphism, and inhibition of $\beta$-carbonic anhydrase of Helicobacter pylori. J. Gastroenterol. 2008, 43, 849-857. [CrossRef] [PubMed]

53. Dedeoglu, N.; DeLuca, V.; Isik, S.; Yildirim, H.; Kockar, F.; Capasso, C.; Supuran, C.T. Sulfonamide inhibition study of the $\beta$-class carbonic anhydrase from the caries producing pathogen Streptococcus mutans. Bioorg. Med. Chem. Lett. 2015, 25, 2291-2297. [CrossRef] [PubMed]

54. Dedeoglu, N.; de Luca, V.; Isik, S.; Yildirim, H.; Kockar, F.; Capasso, C.; Supuran, C.T. Cloning, characterization and anion inhibition study of a $\beta$-class carbonic anhydrase from the caries producing pathogen Streptococcus mutans. Bioorg. Med. Chem. 2015, 23, 2995-3001. [CrossRef] [PubMed]

55. Alafeefy, A.M.; Ceruso, M.; Al-Tamimi, A.M.; Del Prete, S.; Supuran, C.T.; Capasso, C. Inhibition studies of quinazoline-sulfonamide derivatives against the $\gamma$-CA (PgiCA) from the pathogenic bacterium, Porphyromonas gingivalis. J. Enzym. Inhib. Med. Chem. 2015, 30, 592-596. [CrossRef] [PubMed]

56. Vullo, D.; del Prete, S.; Osman, S.M.; de Luca, V.; Scozzafava, A.; Alothman, Z.; Supuran, C.T.; Capasso, C. Sulfonamide inhibition studies of the $\gamma$-carbonic anhydrase from the oral pathogen Porphyromonas gingivalis. Bioorg. Med. Chem. Lett. 2014, 24, 240-244. [CrossRef] [PubMed]

57. Del Prete, S.; Vullo, D.; de Luca, V.; Carginale, V.; Scozzafava, A.; Supuran, C.T.; Capasso, C. A highly catalytically active $\gamma$-carbonic anhydrase from the pathogenic anaerobe Porphyromonas gingivalis and its inhibition profile with anions and small molecules. Bioorg. Med. Chem. Lett. 2013, 23, 4067-4071. [CrossRef] [PubMed]

58. Vullo, D.; Sai Kumar, R.S.; Scozzafava, A.; Capasso, C.; Ferry, J.G.; Supuran, C.T. Anion inhibition studies of a $\beta$-carbonic anhydrase from Clostridium perfringens. Bioorg. Med. Chem. Lett. 2013, 23, 6706-6710. [CrossRef] [PubMed]

59. Maresca, A.; Scozzafava, A.; Kohler, S.; Winum, J.Y.; Supuran, C.T. Inhibition of $\beta$-carbonic anhydrases from the bacterial pathogen Brucella suis with inorganic anions. J. Inorg. Biochem. 2012, 110, 36-39. [CrossRef] [PubMed]

60. Vullo, D.; Nishimori, I.; Scozzafava, A.; Kohler, S.; Winum, J.Y.; Supuran, C.T. Inhibition studies of a $\beta$-carbonic anhydrase from Brucella suis with a series of water soluble glycosyl sulfanilamides. Bioorg. Med. Chem. Lett. 2010, 20, 2178-2182. [CrossRef] [PubMed]

61. Del Prete, S.; Vullo, D.; di Fonzo, P.; Osman, S.M.; AlOthman, Z.; Supuran, C.T.; Capasso, C. Anion inhibition profiles of the $\gamma$-carbonic anhydrase from the pathogenic bacterium Burkholderia pseudomallei responsible of melioidosis and highly drug resistant to common antibiotics. Bioorg. Med. Chem. 2017, 25, 575-580. [CrossRef] [PubMed]

62. Vullo, D.; Nishimori, I.; Minakuchi, T.; Scozzafava, A.; Supuran, C.T. Inhibition studies with anions and small molecules of two novel $\beta$-carbonic anhydrases from the bacterial pathogen Salmonella enterica serovar typhimurium. Bioorg. Med. Chem. Lett. 2011, 21, 3591-3595. [CrossRef] [PubMed]

63. Nishimori, I.; Minakuchi, T.; Vullo, D.; Scozzafava, A.; Supuran, C.T. Inhibition studies of the $\beta$-carbonic anhydrases from the bacterial pathogen Salmonella enterica serovar typhimurium with sulfonamides and sulfamates. Bioorg. Med. Chem. 2011, 19, 5023-5030. [CrossRef] [PubMed]

64. Burghout, P.; Vullo, D.; Scozzafava, A.; Hermans, P.W.; Supuran, C.T. Inhibition of the $\beta$-carbonic anhydrase from Streptococcus pneumoniae by inorganic anions and small molecules: Toward innovative drug design of antiinfectives? Bioorg. Med. Chem. 2011, 19, 243-248. [CrossRef] [PubMed] 
65. Ceruso, M.; Vullo, D.; Scozzafava, A.; Supuran, C.T. Sulfonamides incorporating fluorine and 1,3,5-triazine moieties are effective inhibitors of three $\beta$-class carbonic anhydrases from Mycobacterium tuberculosis. J. Enzym. Inhib. Med. Chem. 2014, 29, 686-689. [CrossRef] [PubMed]

66. Nishimori, I.; Minakuchi, T.; Maresca, A.; Carta, F.; Scozzafava, A.; Supuran, C.T. The $\beta$-carbonic anhydrases from Mycobacterium tuberculosis as drug targets. Curr. Pharm. Des. 2010, 16, 3300-3309. [CrossRef] [PubMed]

67. Carta, F.; Maresca, A.; Covarrubias, A.S.; Mowbray, S.L.; Jones, T.A.; Supuran, C.T. Carbonic anhydrase inhibitors. Characterization and inhibition studies of the most active $\beta$-carbonic anhydrase from Mycobacterium tuberculosis, rv3588c. Bioorg. Med. Chem. Lett. 2009, 19, 6649-6654. [CrossRef] [PubMed]

68. Innocenti, A.; Zimmerman, S.; Ferry, J.G.; Scozzafava, A.; Supuran, C.T. Carbonic anhydrase inhibitors. Inhibition of the $\beta$-class enzyme from the methanoarchaeon Methanobacterium thermoautotrophicum (Cab) with anions. Bioorg. Med. Chem. Lett. 2004, 14, 4563-4567. [CrossRef] [PubMed]

69. Innocenti, A.; Zimmerman, S.; Ferry, J.G.; Scozzafava, A.; Supuran, C.T. Carbonic anhydrase inhibitors. Inhibition of the zinc and cobalt $\gamma$-class enzyme from the archaeon Methanosarcina thermophila with anions. Bioorg. Med. Chem. Lett. 2004, 14, 3327-3331. [PubMed]

70. Vullo, D.; de Luca, V.; Scozzafava, A.; Carginale, V.; Rossi, M.; Supuran, C.T.; Capasso, C. The first activation study of a bacterial carbonic anhydrase (CA). The thermostable $\alpha$-CA from Sulfurihydrogenibium yellowstonense YO3AOP1 is highly activated by amino acids and amines. Bioorg. Med. Chem. Lett. 2012, 22, 6324-6327. [CrossRef] [PubMed]

71. Vullo, D.; Luca, V.D.; Scozzafava, A.; Carginale, V.; Rossi, M.; Supuran, C.T.; Capasso, C. The $\alpha$-carbonic anhydrase from the thermophilic bacterium Sulfurihydrogenibium yellowstonense YO3AOP1 is highly susceptible to inhibition by sulfonamides. Bioorg. Med. Chem. 2013, 21, 1534-1538. [CrossRef] [PubMed]

72. De Luca, V.; Vullo, D.; Scozzafava, A.; Carginale, V.; Rossi, M.; Supuran, C.T.; Capasso, C. Anion inhibition studies of an $\alpha$-carbonic anhydrase from the thermophilic bacterium Sulfurihydrogenibium yellowstonense YO3AOP1. Bioorg. Med. Chem. Lett. 2012, 22, 5630-5634. [CrossRef] [PubMed]

73. Alafeefy, A.M.; Abdel-Aziz, H.A.; Vullo, D.; Al-Tamimi, A.M.; Al-Jaber, N.A.; Capasso, C.; Supuran, C.T. Inhibition of carbonic anhydrases from the extremophilic bacteria Sulfurihydrogenibium yellostonense (Sspca) and S. azorense (Sazca) with a new series of sulfonamides incorporating aroylhydrazone-, $[1,2,4]$ triazolo[3,4- $b][1,3,4]$ thiadiazinyl- or 2-(cyanophenylmethylene)-1,3,4-thiadiazol-3(2H)-yl moieties. Bioorg. Med. Chem. 2014, 22, 141-147. [PubMed]

74. Vullo, D.; de Luca, V.; Scozzafava, A.; Carginale, V.; Rossi, M.; Supuran, C.T.; Capasso, C. The extremo- $\alpha$-carbonic anhydrase from the thermophilic bacterium Sulfurihydrogenibium azorense is highly inhibited by sulfonamides. Bioorg. Med. Chem. 2013, 21, 4521-4525. [CrossRef] [PubMed]

75. Akdemir, A.; Vullo, D.; de Luca, V.; Scozzafava, A.; Carginale, V.; Rossi, M.; Supuran, C.T.; Capasso, C. The extremo- $\alpha$-carbonic anhydrase (CA) from Sulfurihydrogenibium azorense, the fastest ca known, is highly activated by amino acids and amines. Bioorg. Med. Chem. Lett. 2013, 23, 1087-1090. [CrossRef] [PubMed]

76. Vullo, D.; de Luca, V.; Scozzafava, A.; Carginale, V.; Rossi, M.; Supuran, C.T.; Capasso, C. Anion inhibition studies of the fastest carbonic anhydrase (CA) known, the extremo-ca from the bacterium Sulfurihydrogenibium azorense. Bioorg. Med. Chem. Lett. 2012, 22, 7142-7145. [CrossRef] [PubMed]

77. Vullo, D.; de Luca, V.; del Prete, S.; Carginale, V.; Scozzafava, A.; Capasso, C.; Supuran, C.T. Sulfonamide inhibition studies of the $\gamma$-carbonic anhydrase from the antarctic bacterium pseudoalteromonas haloplanktis. Bioorg. Med. Chem. Lett. 2015, 25, 3550-3555. [CrossRef] [PubMed]

78. De Luca, V.; Vullo, D.; del Prete, S.; Carginale, V.; Scozzafava, A.; Osman, S.M.; AlOthman, Z.; Supuran, C.T.; Capasso, C. Cloning, characterization and anion inhibition studies of a new $\gamma$-carbonic anhydrase from the antarctic bacterium Pseudoalteromonas haloplanktis. Bioorg. Med. Chem. 2015, 23, 4405-4409. [CrossRef] [PubMed]

79. Del Prete, S.; De Luca, V.; Supuran, C.T.; Capasso, C. Protonography, a technique applicable for the analysis of $\eta$-carbonic anhydrase activity. J. Enzym. Inhib. Med. Chem. 2015, 1-5. [CrossRef] [PubMed]

80. Del Prete, S.; De Luca, V.; Iandolo, E.; Supuran, C.T.; Capasso, C. Protonography, a powerful tool for analyzing the activity and the oligomeric state of the $\gamma$-carbonic anhydrase identified in the genome of Porphyromonas gingivalis. Bioorg. Med. Chem. 2015, 23, 3747-3750. [CrossRef] [PubMed]

81. De Luca, V.; del Prete, S.; Supuran, C.T.; Capasso, C. Protonography, a new technique for the analysis of carbonic anhydrase activity. J. Enzym. Inhib. Med. Chem. 2015, 30, 277-282. [CrossRef] [PubMed] 
82. Khalifah, R.G. The carbon dioxide hydration activity of carbonic anhydrase. I. Stop-flow kinetic studies on the native human isoenzymes B and C. J. Biol. Chem. 1971, 246, 2561-2573. [PubMed]

83. Laemmli, U.K. Cleavage of structural proteins during the assembly of the head of bacteriophage T4. Nature 1970, 227, 680-685. [CrossRef] [PubMed]

Sample Availability: Samples of the recombinant protein $(\mathrm{BpsCA} \beta)$ and compounds are available from the authors.

(c) (2) BY (c) 2017 by the authors. Licensee MDPI, Basel, Switzerland. This article is an open access article distributed under the terms and conditions of the Creative Commons Attribution (CC BY) license (http:/ / creativecommons.org/licenses/by/4.0/). 